\title{
O Círculo de giz caucasiano pela Companhia do Latão
}

The Caucasian Chalk Circle by the Companhia do Latão

Sonia Pascolati ${ }^{1}$ 


\section{Resumo}

Neste artigo, apresento uma reflexão sobre o processo de atualização cênica do texto $O$ Círculo de giz caucasiano (1943-1945), um dos mais densos de Bertolt Brecht, a partir da análise do espetáculo montado pela Companhia do Latão em 2006. O grupo tem como referência as técnicas do teatro épico brechtiano, portanto, a leitura do espetáculo torna evidentes a concepção de teatro épico e os recursos que possibilitam o efeito de distanciamento, aspectos destacados tanto na análise do texto quanto do espetáculo.

Palavras-chave: Teatro político; Teatro épico; Companhia do Latão; Bertolt Brecht

\section{Abstract}

In this paper, I present a reflection on the process of updating the scenic text The Caucasian Chalk Circle (19431945), one of the densest of Brecht, from the spectacle of Companhia do Latão in 2006. The Companhia do Latão makes reference to the techniques of Brechtian epic theater, so the reading of the theatrical performance makes evident the concept of epic theater and resources that enable the distancing effect, highlighted aspects both in the analysis of the text as the theatrical performance.

Keywords: Political theater; Epic theater; Companhia do Latão; Bertolt Brecht

ISSN: 1414.5731

E-ISSN: 2358.6958 ${ }^{1}$ Professora doutora do Programa de Pós-Graduação em Letras e do Programa de Mestrado Profissional em Letras - PROFLETRAS - da Universidade Estadual
de Londrina (UEL). sopasco@hotmail.com 


\section{Introdução}

Por muitas razões Bertolt Brecht (1898-1956) é um dos nomes mais importantes do teatro do século $X X$, mas especialmente pela reflexão que seus textos e a prática teatral idealizada e praticada por ele propiciam no campo político, sobretudo o questionamento das bases sobre as quais se constrói a sociedade capitalista e seus renovados mecanismos de opressão, desigualdade e manipulação ideológica. Estes são os aspectos que mais interessam à Companhia do Latão, trupe estabelecida em São Paulo como grupo de pesquisa (Projeto "Pesquisa em Teatro Dialético") em 1996 e dirigido por Sérgio de Carvalho e Márcio Marciano. A partir de 2006, passa a estar exclusivamente sob a direção de Sérgio de Carvalho, sendo a primeira montagem exatamente a do Círculo de giz caucasiano, objeto de análise deste artigo. O grupo conta com longo repertório de espetáculos e experimentos cênicos cuja base teórica é o conceito de teatro dialético, tão caro ao dramaturgo alemão. Para a estudiosa Iná Camargo Costa, dentre as tantas funções reconhecíveis para o teatro, a Companhia do Latão "[...] declara ser função de seu teatro colaborar com a ativação revolucionária num tempo em que isso não está num horizonte próximo e, para isso, reatualiza a palavra de ordem brechtiana de narrar o mundo como transformável" (Costa, 2008, p. 15).

Um mundo transformável tem de reconhecer as contradições que o habitam e perpassam as relações sociais e econômicas. A Companhia do Latão não perde isso de vista até hoje, ao contrário de outros grupos e experimentos teatrais para quem Brecht é um conjunto de técnicas (épicas) das quais se pode apropriar de modo independente das questões políticas e econômicas.

Ao contrário dos lógicos, que aceitavam a premissa de que um princípio evidente dispensa demonstração, na dialética de base hegeliana o princípio de identidade - qual seja, se um princípio é verdadeiro, então ele é verdadeiro -

não só não é revogado como ainda é reconhecido como necessário à progressão das categorias e conceitos, à medida que as contradições vão sendo ultrapassadas e incorporadas ao conhecimento de cada um deles. O que a dialética recusa é a aplicação unilateral da categoria isolada - pois isto significa evitar, negligenciar e assim tornar insolúveis as contradições. (Costa, 2008, p. 20).

Análises da sociedade capitalista, pautada pelo consumo de bens materiais (do qual boa parcela da população é excluída) e manipulada pelos meios de comunicação que fazem circular discursos que confundem cidadania com poder de consumo, não podem deixar de considerar a importância da contradição. No volume que reúne sete peças experimentais do grupo, Sérgio de Carvalho faz questão de registrar, já na apresentação, a importância da

herança de Büchner e Brecht, dramaturgos modelares em vários aspectos: pela

\footnotetext{
${ }^{2}$ O espetáculo 0 Círculo de giz caucasiano, direção de Sérgio de Carvalho, música de Martin Eikmeier, com a Companhia do Latão e artistas convidados, a partir do texto de Brecht na tradução de Manuel Bandeira, estreou no Rio de Janeiro em 9.08.2006. No elenco Helena Albergaria, Ney Piacentini, Deborah Lobo, Carlota Joaquina, Luís Mármora, Cibele Jácome, Rodrigo Bolzan, Mafa Nogueira, Rogério Bandeira, Sidney Ferreira. Execução Musical Mafa Nogueira e Martin Eikmeier. Assistência de direção Daniele Ricieri; preparadora vocal Sandra Ximenez; cenário e figurinos Fábio Namatame; assistência de cenário Bruno Anselmo; produção João Pissarra. O vídeo do prólogo foi gravado no assentamento Carlos Lamarca, ligado ao MST, em Sarapuí (SP), com direção e montagem de Caetano Gotardo, Diogo Noventa, Marco Dutra e Sérgio de Carvalho. Direção de Fotografia Matheus Rocha, som direto Luiz Gustavo Cruz e participação especial do grupo teatral Filhos da Mãe Terra" (Marciano, 2006, p. 175).
} 
Capacidade de pôr em crise os padrões convencionais do drama, na disposição à experimentação formal, no interesse pela representação dos estragos da vida na sociedade capitalista. Foram, para nós, modelos para uma dialética aplicada ao teatro, utilizados de acordo com nossas necessidades de luta, conforme nosso tempo e lugar. (Carvalho; Marciano, 2008, p. 11)

Ao final do mesmo volume, há a apresentação do histórico da companhia ${ }^{3}$ em cujo conjunto é destacada a importância do espetáculo $O$ círculo de giz caucasiano:

A estreia em agosto de 2006 de $O$ círculo de giz caucasiano, com direção de Sérgio de Carvalho e artistas oriundos de vários grupos de pesquisa, é mais que um retorno a Brecht. Inaugura um procedimento de cooperações e uma intensa produção de experimentos audiovisuais. [...] O círculo de giz caucasiano é apresentado em Havana onde obtém o prêmio Villanueva, como melhor espetáculo estrangeiro de 2007, concedido pela União dos Escritores e Artistas de Cuba. O Estúdio do Latão é inaugurado em julho do mesmo ano e passa a sediar oficinas e abrigar uma pesquisa teatral e audiovisual intitulada Ópera dos vivos, que se desdobra entre 2008 e 2009. (Carvalho; Marciano, 2008, p. 410).

O espetáculo resultante das pesquisas audiovisuais do Latão, mencionado ao final da citação (Ópera dos vivos), estreou em $2010^{4}$ e sinaliza a continuidade dos produtivos diálogos da companhia com o pensamento teatral e político de Brecht. O processo de ensaios do espetáculo deixou claro para o grupo o objetivo de "[...] discutir as formas da indústria cultural brasileira a partir do embate com seu passado, numa investigação sobre as contradições entre ideias e situações produtivas" (Blog..., 2015). O resultado mais amplo é a demonstração de que as propostas estéticas e políticas de Brecht continuam atuais e válidas ${ }^{5}$ como instrumento de reflexão sobre as configurações da sociedade capitalista neste século XXI.

Este artigo propõe uma leitura do fenômeno teatral em sua dupla enunciação: como texto e espetáculo. O Círculo de giz caucasiano é uma das obras mais instigantes de Brecht, uma das que congrega maior número de recursos épicos em sua construção. A Companhia do Latão, grupo profissional que completa 20 anos de profícua atividade teatral em 2016, elaborou uma bela montagem do texto, afinada com os princípios épicos de encenação. O espetáculo $O$ Círculo de giz caucasiano foi apresentado na cidade de Londrina/Paraná em junho de 2007, durante a 39ạ. edição do FILO - Festival Internacional de Londrina, ocasião em que pude assistir ao espetáculo e observar as técnicas e recursos épicos utilizados no palco. O trabalho de análise do espetáculo aprimorou-se com uma segunda oportunidade de assisti-lo, dessa vez na cidade de Araraquara/ SP, em julho do mesmo ano, durante mostra de teatro promovida pelo SESC/SP, ocasião em que participei de um workshop com o grupo e seu diretor.

Partindo do texto dramático, proponho uma análise dos recursos épicos tanto do texto quanto da representação construída pela Companhia do Latão, afinal, em ambos é clara a orientação épica e política.

\footnotetext{
${ }^{3}$ Informações disponíveis no endereço http://www.companhiadolatao.com.br/html/historia/index.htm. A transcrição utilizada é da publicação referenciada ao fim da citação. ${ }^{4} \mathrm{O}$ espetáculo participou da $3^{\mathrm{a}}$. Mostra de Teatro Contemporâneo, promovida pela Cia. Teatro e Ponto, dirigida por Márcio Alex Pereira, e pelo Grupo de Pesquisa Crítica Materialista, coordenado por Alexandre Flory, na UEM. A apresentação foi na Oficina de Teatro da UEM nos dias 17 e 18 de agosto de 2013.

${ }^{5}$ O espetáculo Ópera dos vivos não é construído a partir de um texto de Brecht, mas dialoga tanto com as propostas teatrais do alemão quanto com sua recepção no Brasil desde os anos 1960, com ênfase para a base materialista e dialética do pensamento e da prática teatral brechtianos.
} 


\section{Brecht: teatro épico, político, dialético}

As obras de Brecht são um marco na (r)evolução do teatro moderno no Ocidente, redirecionando o curso das experimentações dramatúrgicas e cênicas do século XX. O autor alemão é um homem de teatro no sentido pleno da expressão: escreve textos para o teatro, dirige, atua. O legado de Brecht não se limita à produção como dramaturgo; pelo contrário, os registros de sua atuação na direção do grupo Berliner Ensemble e seus escritos teóricos constituem um documento vital para a compreensão dos rumos adotados pelo drama moderno.

Peter Szondi (2003), quando propõe sua teoria do drama moderno, localiza nas duas últimas décadas do século XIX um conjunto de peças e dramaturgos representantes do que nomeia "crise do drama". O indício principal dessa crise é a inadequação entre os novos temas dos dramas e a forma tradicional do gênero; dito de outro modo, o elemento responsável pela renovação do drama nas primeiras décadas do século XX é a busca de soluções dramatúrgicas para o descompasso entre forma e conteúdo.

Analisando obras de Ibsen, Tchékhov, Strindberg, Maeterlink e Hauptmann, Szondi (2003) chega a um conjunto de traços comuns, caracterizando assim a "crise do drama": a) presença do passado no palco por meio da memória das personagens; b) construção de personagens solitárias, isoladas e voltadas para si mesmas - portanto, pouco afeitas ao diálogo, pedra basilar do drama tradicional; c) diálogo, compreendido como interação intersubjetiva, sempre mais rarefeito; d) presença de elementos épicos exigidos pela temática (temas sociais e de investigação psicológica, por exemplo) abordada pelos dramaturgos. A conclusão do autor é que, gradativamente, a forma dramática recebe em seu interior elementos épicos que conduzem a uma acentuada "epicização" do drama.

Dentre esses elementos, vale destacar, em Ibsen, o fato de o tempo tornar-se tema das peças, tempo passado que se faz presente pelo relato das personagens. Sobre Tchékhov, Szondi destaca a recusa em construir o drama sobre os pilares tradicionais da ação e do diálogo, o que leva suas personagens a expor discursivamente seus sonhos (e frustrações) em vez de agir para realizá-los, resultando "[...] na retirada formal do diálogo [que] conduz necessariamente ao épico" (Szondi, 2003, p. 53). O épico em Strindberg instaura-se pela fragmentação característica do "drama de estação" no qual o encadeamento lógico-causal da ação, tal como exposto por Aristóteles, se desfaz pela apresentação de cenas cujo elo passa a ser a subjetividade de um "eu". Já em Maeterlink, "[...] a substituição da categoria de ação pela de situação" (Szondi, 2003, p. 70) materializa a presença do épico na medida em que as personagens falam sobre sua própria condição (narrativização da situação dramática) em vez de fazê-la acontecer dramaticamente diante do espectador. Por fim, no drama social produzido por Hauptmann, o fato de organizar-se em torno de uma temática e um contexto social e político que se projeta para além da forma fechada do drama fazem com que ele tenha "essência épica", pois que remete a algo "extrínseco" ao drama, o que corresponde a um princípio formal da épica e não da dramática (Szondi, 2003, p. 77). 
De acordo com Szondi, após a percepção da crise do drama, ilustrada pela emersão de elementos épicos na dramaturgia dos cincos autores comentados acima, existem "tentativas de salvamento" da forma dramática, exemplificadas pelo teórico por meio de quatro procedimentos. Entretanto, trata-se de tentativas fracassadas, já que o épico insiste em fazer-se presente.

O naturalismo é a primeira tentativa de salvamento. Ele adere a uma nova categoria de herói, aquele que representa o campesinato e o proletariado, portanto, o trabalhador em lugar do burguês. Essa alteração leva o drama a tomar distância épica das personagens que coloca em cena, ou seja, "[...] uma classe observa a outra: o poeta burguês e o público constituído pela burguesia observam o campesinato e o proletariado" (Szondi, 2003, p. 103). O resultado é uma "[...] ação coagulada, que não se integra perfeitamente aos caracteres e a seu meio ambiente" (Szondi, 2003, p. 104).

Se a ação não consegue manter seu dinamismo dramático no naturalismo, na peça de conversação é o diálogo que se tenta salvar. Entretanto, ao se metamorfosear em monólogos, essa espécie de diálogo revela mais a impossibilidade das relações intersubjetivas do que a realização dialógica do drama. Em vez do diálogo que movimenta a ação e faz desenrolar o conflito, há a conversação, num ensaio, frustrado, de manter o diálogo como categoria dramática básica. Portanto, com o desaparecimento da "relação intersubjetiva, o diálogo se despedaça em monólogos" (Szondi, 2003, p.105), o que o leva a tornar-se conversação.

Também a peça em um só ato é uma tentativa de salvação da forma dramática na medida em que procura preservar a tensão como elemento fundamental do estilo dramático, conforme teoriza Emil Staiger (1997). Todavia, não consegue fazer com que a tensão permaneça como mola propulsora da ação porque se concentra em um momento específico de tensão, remetendo mais à imobilidade do que ao dinamismo próprio do drama absoluto. Essa constatação autoriza Szondi (2003, p. 110) a afirmar que "[...] a peça de um ato só partilha com o drama o seu ponto de partida, a situação, mas não a ação, na qual as decisões das dramatis personae modificam continuamente a situação de origem e tendem ao ponto final do desenlace".

A última tentativa de salvação do drama é a colocação das personagens em situação de confinamento, portanto, elas estão isoladas e são obrigadas a dialogar e relacionar-se intersubjetivamente, não podendo simplesmente apelar ao silêncio ou ao monólogo. Trata-se de uma tentativa de salvamento do diálogo, mas ele sobrevive apenas como troca de réplicas e tréplicas entre as personagens, logo, acaba caminhando em direção ao épico quando o que deseja é exatamente o contrário.

Surgem também algumas "tentativas de solução" da crise, mas a fim de que essa resenha do pensamento szondiano não se alongue desnecessariamente, deixarei de comentar a dramaturgia do eu, de cunho expressionista; o monólogo interior; a impossibilidade do drama transformada em tema do próprio drama, como faz Pirandello; o eu-épico como diretor de cena; dentre outros procedimentos analisados por Szondi a partir da obra de expressivos dramaturgos do século XX. Passo diretamente a Brecht, cujo teatro épico está entre as tentativas de solução da crise do drama que configurarão o que chamamos de modernidade teatral.

O teatro épico brechtiano ocupa um lugar especial no cenário de surgimento do drama moderno. Se não podemos afirmar que Brecht é o criador do teatro épico, 
pois realizações dramáticas assim nomeadas lhe são anteriores, temos de reconhecer que ele confere ao conceito de "teatro épico" uma nova formulação. O significado específico do termo "épico" em alemão é "uma forma de narrativa" e quando empregado por Brecht remete a "uma seqüência de incidentes ou eventos, narrados sem restrições artificiais quanto ao tempo, lugar ou relevância para um 'enredo' formal" (Willett, 1967, p. 217). A nova formulação do termo não se despe, entretanto, do sentido anterior de conjunto de técnicas que acentuam a narração no teatro, tais como projeção de filmes, inserção de títulos das cenas, uso da meia-cortina para revelar os bastidores do teatro, entre outros recursos especificamente brechtianos como canções que interrompem as cenas, contribuindo para que elas sejam mais independentes umas das outras; personagens que se apresentam diretamente ao público; coro com função narrativa, comentando e por vezes até julgando a ação apresentada no palco.

Refletindo sobre a função do teatro e sem negar a dimensão de diversão e fruição estética, o acento recai sobre sua função social. Partindo de uma concepção específica do humano compreendido "como 'o conjunto de todas as condições sociais'", Brecht ([19- ], p.42) propõe um teatro que atenda a essa nova configuração social. $O$ centro de sua atenção é o homem em suas determinações históricas, o homem que ocupa as poltronas do teatro, mas é capaz de perceber as implicações entre a realidade exterior e o que é mostrado no palco. Na verdade, todas as modificações propostas em relação à forma dramática do teatro - ou drama aristotélico têm em vista o espectador; é na relação entre palco e público que os recursos épicos se associam ao efeito de distanciamento.

No texto "Efeitos de distanciamento na arte dramática chinesa" há uma afirmação a partir da qual se deduz que a arte dramática descrita por Aristóteles, para Brecht, se fundamenta na empatia, isto é, na identificação dos sentimentos do espectador com os sentimentos das personagens, estes, por sua vez, confundidos com os sentimentos do ator. O efeito de distanciamento é exatamente o contrário e Brecht exemplifica comentando tentativas de dramaturgia não-aristotélica nas quais se desenvolvesse

a representação de tal modo que fosse impossível ao espectador meter-se na pele das personagens da peça. A aceitação ou a recusa das palavras ou das ações das personagens devia efetuar-se no domínio do consciente do espectador, e não, como até a esse momento, no domínio do seu subconsciente. (Brecht ([19- ], p. 89))

Rosenfeld aponta magistralmente a forma como a dialética perpassa e determina a concepção brechtiana do efeito de distanciamento:

A teoria do distanciamento é, em si mesma, dialética. O tornar estranho, o anular da familiaridade da nossa situação habitual, a ponto de ela ficar estranha a nós mesmos, torna em nível mais elevado esta nossa situação mais conhecida e mais familiar. $\mathrm{O}$ distanciamento passa então a ser a negação da negação; leva através do choque do não-conhecer ao choque do conhecer. Trata-se de um acúmulo de incompreensibilidade até que surja a compreensão. Tornar estranho é, portanto, ao mesmo tempo tornar conhecido. A função do distanciamento é a de se anular a si mesma. (Rosenfeld, 1997, p. 152) 
Nas notas sobre a peça $A$ mãe ("O efeito mediato do teatro épico"), a oposição entre dramaturgia aristotélica e não-aristotélica se dá em outros termos, destacando a ação do espetáculo sobre o comportamento concreto do público, ou melhor, sublinhando a importância do teatro para a compreensão da realidade social que determina os indivíduos.

\begin{abstract}
A estética aceite hoje em dia, ao exigir um efeito imediato, exige também, da obra de arte, um efeito que supere as diferenças sociais e as restantes diferenças que existem entre os indivíduos. Esse efeito de superação dos antagonismos de classes é ainda conseguido atualmente por dramas de dramática aristotélica, se bem que os indivíduos cada vez tenham mais consciência das diferenças de classe. [...] Seja qual for o caso, cria-se entre os espectadores um todo coletivo, surgido a partir do "humano universal", comum a todo o auditório, durante o tempo da fruição artística. A dramática não-aristotélica, do tipo de $A$ mãe, não está interessada na produção deste gênero de coletivismo e, muito pelo contrário, divide o seu público. (Brecht, [19- ], p. 69)
\end{abstract}

A distinção é óbvia: ao passo que a dramaturgia aristotélica tende a mostrar o homem como universal - portanto, suprimindo a historicidade que o atravessa - a dramaturgia não aristotélica procura sublinhar as diferenças entre os homens, particularmente no que diz respeito aos antagonismos de classe evidenciados no palco a fim de serem superados na realidade.

Um teatro dialético tem por função revelar as desigualdades, apontar as contradições da sociedade industrial. É apenas dialeticamente que várias perspectivas de um mesmo objeto podem ser evidenciadas; o pensamento dialético procura revelar uma antítese para cada tese proposta, uma espécie de desmonte de raciocínios. $O$ método dialético é útil para colocar em xeque verdades cristalizadas e aceitas como naturais pelo homem. Segundo Sábato Magaldi (1997, p. 10), "a forma épica foi a que melhor se prestou à caracterização de uma dramaturgia de crítica marxista da sociedade", especialmente num cenário de recrudescimento do capitalismo, produtor de mitologias mais encobertas do que aquelas da tradição grega ou da religião porque se trata de um modo de produção apoiado no cientificismo. O objetivo é descortinar as contradições dessa sociedade capitalista de seu próprio interior, representando teatralmente seus mecanismos de dominação ideológica e econômica.

O teatro épico é a forma encontrada por Brecht para realizar na prática aquilo que ele acredita ser o papel do teatro, ou ainda, aquilo que ele compreende por teatro: um espaço para o conhecimento do ser humano, espaço onde o homem aprende e (re)conhece a si mesmo; instrumento de reflexão e terreno fértil para a filosofia; manifestação artística por meio da qual o funcionamento das relações sociais pode ser revelado, possibilitando e estimulando a transformação social, a intervenção do homem no mundo (Peixoto, 1981).

\title{
O épico no texto
}

O círculo de giz caucasiano tem como cenário inicial "as ruínas de uma aldeia caucasiana bombardeada" (Brecht, 1992, p.183), remetendo diretamente à Segunda 
Guerra Mundial. Confirmando o que anuncia o título da cena - O vale em questão -, camponeses estão em círculo discutindo o destino de um vale. Considerando o contexto do pós-guerra, instaura-se uma discussão sobre como decidir coletivamente o destino de algo que pertence a uma coletividade. Um grupo, representando o colcós Rosa Luxemburgo, o quer para o cultivo de frutas e vinhedos e o outro, do colcós Galinski, para o pastoreio de cabras. O primeiro grupo tem um bom plano de irrigação que tornará as terras mais produtivas e férteis; após a apresentação dos argumentos de ambos os grupos, decide-se que o colcós Galinski cederá o vale e colaborará com o plano de irrigação do colcós Rosa Luxemburgo. Isso confirma a máxima expressa pela Moça Tratorista - "Em cada caso as leis precisam ser revistas, para ver se ainda podem vigorar" (Brecht, 1992, p.185) - e antecipa o leitmotiv da peça: deve possuir a terra ou outro bem qualquer aquele que melhor cuidar dele, mesmo que não seja seu legítimo dono. Aliás, a atuação de Hitler na Europa obrigou a rever tanto a noção de legitimidade quanto a de propriedade, questão que atravessa toda a peça.

A reunião dos camponeses constitui a peça moldura, ou primeiro nível do texto, pois se trata de uma construção em abismo (mise en abyme - narrativa dentro da narrativa, peça dentro da peça) na qual um novo nível se desdobra do anterior. O segundo nível dramatúrgico é composto por outra narrativa, uma velha lenda chinesa que guarda íntima relação com a disputa pelo vale. Aqui já observamos o primeiro recurso épico: a narração/ representação de uma história. Um grupo conduzido pelo cantor Arkadi Tscheidzê se propõe a representar para os camponeses a história da família do governador Geórgi Abaschvíli, destituído do poder e enforcado após uma revolução, cujo filho ainda bebê é abandonado no palácio e acolhido pela empregada Grusche. Depois de dois anos, com outra mudança no poder, a mulher do governador retorna e requer a posse do filho Miguel a fim de reaver seus bens. A questão da posse se recoloca em outro contexto, mas reforça o raciocínio da primeira situação dramática: deve ficar com a criança a mãe de sangue ou aquela que cuidou dele, arriscando sua própria vida?

Interessante registrar que se trata, em ambas as situações, de considerar as circunstâncias históricas e políticas em que os fatos acontecem, assim como o espelhamento entre as situações dramáticas (moldura e de encaixe) evoca uma mesma questão: os homens devem decidir, em consonância com as determinações históricas e ideológicas de seu tempo, o que é melhor para a comunidade, o que implica uma adesão do indivíduo ao coletivo.

No momento em que se deve decidir quem fica com a criança, há um retrocesso temporal necessário para conhecermos a trajetória de uma nova personagem, o juiz Asdak, responsável pelo julgamento do destino do menino Miguel. O letreiro "A história de um juiz" anuncia o quinto quadro da peça e narra como o simples escrivão de aldeia Asdak foi promovido a juiz numa brincadeira inconsequente de alguns homens do povo. Vestido com toga, Asdak passa a exercer uma justiça que não segue nenhuma lei preestabelecida e/ou legitimada, mas tem como princípio remediar os pobres e arrancar dinheiro dos ricos para seu próprio benefício. A introdução desse novo fio de intriga é feita por meio de um recurso narrativo. O cantor Arkadi anuncia, numa forma tipicamente épica de exposição dos fatos: 


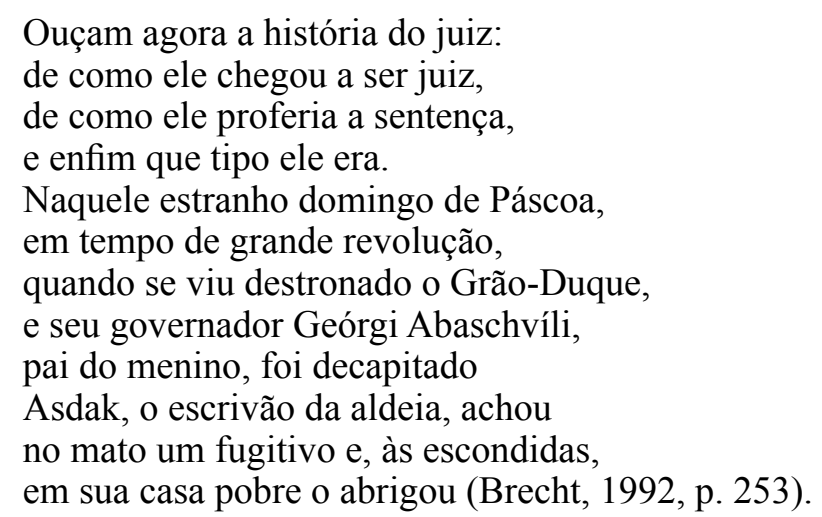

Além de todas as circunstâncias do encontro entre Asdak e o Grão-Duque serem contadas pelo cantor/narrador, essa personagem também promove um recuo no tempo típico do texto narrativo, portanto, signo da intromissão do épico no universo dramático. Trata-se de um flashback que recoloca a ação dois anos antes, no mesmo tempo em que Grusche se apieda do menino e resolve adotá-lo. A essa altura da peça, já se conhece todas as agruras pelas quais a empregada passou para proteger o menino e já se sabe que a mãe legítima reclama a posse do garoto, motivo pelo qual Grusche é presa. Apenas no último quadro - "O círculo de giz" - as histórias de ambos se encontram no tribunal para o julgamento de quem ficará com o menino.

Os diversos níveis dramatúrgicos/narrativos, além de contarem com a presença constante do cantor/narrador, são por si só um recurso épico na medida em que conduzem o leitor/espectador por variados enredos. A justaposição entre as situações dramáticas (disputa pelo vale, pelo menino e a trajetória de Asdak) leva à compreensão de conceitos (justiça, legitimidade, propriedade) de forma dialética, em particular o de justiça, que se constrói pelo atravessamento de concepções éticas relativizadas. No que diz respeito à forma, Brecht recomenda que no teatro épico a ação deva transcorrer em saltos, preceito adotado na construção de $O$ círculo de giz, e que reflete diretamente na possibilidade de dialetização desses conceitos. O efeito de distanciamento, tão querido ao teatro brechtiano, é alcançado por meio desse expediente de descontinuidade entre cenas, ações e núcleos dramáticos.

O recurso da mise en abyme possibilita que o palco abrigue diferentes espaços e tempos. Se a ação tem mais de um núcleo dramático, é natural que tenhamos em cena a passagem do tempo e a migração do vale para a cidade, da cidade para a montanha, e de volta para a cidade. Também o tempo pode deslizar do presente para o passado, obrigando o leitor/espectador a acompanhar os saltos da ação dramática.

O cantor desempenha claramente a função de narrador, de condutor dos fatos e episódios. Além de narrar fatos, como na fala transcrita acima, realiza cortes na ação, anunciando novas cenas e personagens. No quadro 2 , imediatamente após a apresentação da família do governador e sua entrada na igreja para a celebração do domingo de Páscoa, há um corte na cena e passa-se à apresentação de Grusche e do soldado Simon Chachava, seu futuro noivo.

Tranquila está a cidade.

Pombos arrulham na praça da igreja.

Um soldado da guarda do palácio

diz piadas a uma jovem criada 
Esse efeito narrativo atende ao propósito do teatro épico brechtiano de mostrar a cena em vez de representá-la, isto é, os fatos são mostrados (épico, diegético) e não vividos (mimético) pelos atores no palco. Outras vezes, cabe ao cantor a função de comentarista da ação. É o que acontece quando os soldados se insubordinam, primeiro sinal da deposição do governador. Mais do que narrar, o cantor agora propõe uma reflexão sobre a inconstância das coisas e de como se engana o homem que acredita ser eterna sua posição, particularmente no exercício do poder.

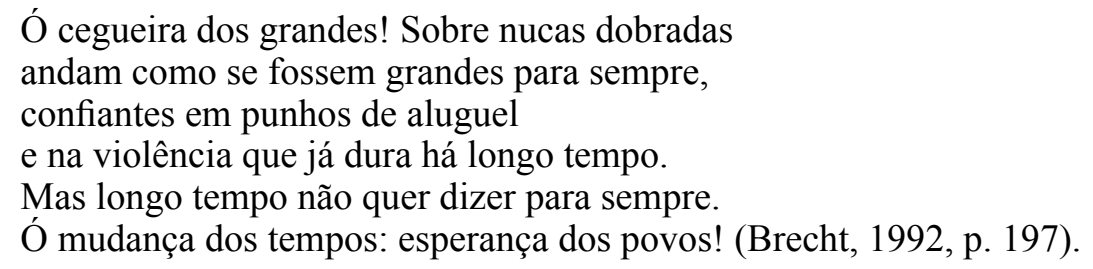

Considerando a historicização em que se ancora o teatro épico, impossível deixar de entrever nessa poética fala do narrador a referência ao contexto histórico imediato: o pós-guerra e a derrota de Hitler. Não há violência que dure para sempre: a história acabara de demonstrar essa verdade.

Na sequência de sua fala, o cantor retoma o tom narrativo do discurso, descrevendo a prisão do governador e agindo como um narrador que realmente atua sobre a personagem, dizendo o que ela deve fazer: "Dê mais uma olhadinha à sua volta, cego!". A rubrica seguinte recomenda: "O prisioneiro olha em redor". Recuperando o diálogo como categoria dramática, o cantor dirige-se diretamente à personagem, admoestando-a: "Vê como é bom o que você foi arranjar?" (Brecht, 1992, p. 198). Podemos perceber por esses poucos exemplos a versatilidade com que elementos épicos são inseridos no texto dramático pelo escritor alemão. Além da presença épica do narrador há ainda o uso de letreiros e/ou cartazes anunciando os títulos das cenas - como os títulos dos capítulos nos romances - e as músicas que narram ou comentam ações, também recursos épicos do teatro brechtiano os quais são realçados na encenação do Latão, como desenvolvido no próximo tópico.

\section{0 épico no palco}

O círculo de giz caucasiano é uma peça cuja estrutura complexa contém recursos do teatro épico conforme pensado e realizado por Brecht; portanto, levar essa peça ao palco é sempre um desafio para um grupo de teatro. O espetáculo da Companhia do Latão é uma feliz realização cênica que incorpora vários elementos épicos previstos pelo texto e pelo método brechtiano de encenação, mas é feliz particularmente porque se preocupa em operar um duplo processo: reavivar o sentido primeiro (histórico) da obra e colocá-lo em relação com o contexto em que é (re)atualizado (também histórico, mas outro), pois, conforme afirma Marciano (2006, p. 175), “[...] não basta o estudo rigoroso da obra a ser encenada para que o sentido original desta se revele em sua inteireza. É preciso antes proceder a um inventário das demandas de re-significação da obra hoje e, assim, aferir sua potência estética e seu alcance 
social".

Neste texto, coloco texto e espetáculo, as duas faces do fenômeno teatral, em diálogo, investigando um mesmo aspecto em ambos os objetos: a presença de elementos épicos. Isso é possível por ter assistido a duas apresentações do espetáculo - na segunda, em Araraquara/ SP, obtive autorização para fotografar algumas cenas - e participado do workshop com o grupo.

Começo a análise do espetáculo pelo prólogo, isto é, o correspondente ao primeiro quadro do texto, intitulado "O vale em questão". Na encenação, ele foi substituído pela exibição de um vídeo, projetado em um telão ao fundo do palco, ao qual assistem a plateia e os atores sentados no chão em círculo - mesma disposição dos camponeses segundo as indicações cênicas do texto. O vídeo foi produzido pelo próprio grupo em oficina realizada com membros do MST - Movimento Sem Terra. Quem esclarece o contexto de produção do vídeo e as intenções do grupo é o diretor Sérgio de Carvalho. As imagens mostram jovens e adultos lendo e preparando a representação das cenas iniciais do texto; durante esses jogos dramáticos, a situação de conflito proposta pelo texto - a posse do vale - é alvo de reflexão, discussão e tomada de posição por parte dos atores-trabalhadores.

Em suas proposições teóricas iniciais, Brecht opera com o conceito de teatro didático, uma forma de tornar o teatro um instrumento de conscientização política das classes trabalhadoras. Brecht empreendeu várias experiências práticas nesse campo, das quais há alguns registros nos escritos teóricos do autor, o que serve como inspiração para a Companhia do Latão.

No espetáculo, o vídeo é um recurso épico, pois funciona como técnica narrativa de exposição da situação inicial da peça; a câmera dirige o olhar do espectador, assim como o cantor/narrador conduz o leitor no texto dramático. Além disso, retratar um universo conhecido do espectador acrescenta uma (nova) dimensão histórica ao texto dramático e à representação. É uma forma de aproximar as fábulas da disputa pela terra e pelo bebê do mundo no qual o espectador do século XXI está inserido. Para Brecht, não é possível conceber e conhecer o homem a não ser historicamente e sempre como ser em transformação, passível de mudanças e com poder para transformar a sociedade em que vive, portanto, o teatro proposto por ele é uma forma de reflexão sobre as circunstâncias sociais, econômicas e políticas que determinam a existência humana.

Outro efeito narrativo é a presença dos títulos dos quadros, também projetados no telão. Trata-se de uma solução cênica para algo proposto pelo próprio texto. $O$ título é como um anúncio explicativo daquilo que será representado. O vídeo traz trechos da peça lidos por membros do MST participantes da oficina promovida pela Companhia do Latão. Após sua exibição, os atores - tal como no texto -, anunciam a representação da velha lenda chinesa; na sequência, temos a projeção do seguinte letreiro: "Para celebrar o encontro, o colcós Rosa Luxemburgo anuncia a representação de uma peça antiga: 'O Círculo de Giz Caucasiano'" (Figura 1). Comparando o expediente dos títulos e letreiros no texto e na peça, percebemos que o grupo mantém o fundamento do recurso, - qual seja, funcionar como elemento narrativo. 


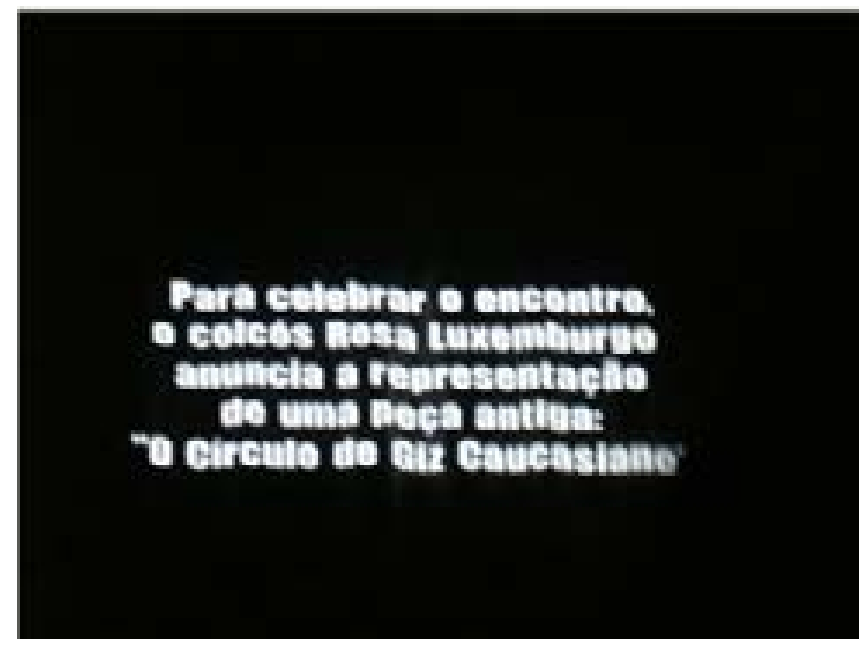

Fonte: Arquivo pessoal. Araraquara, julho 2007

Funciona também como elemento narrativo a técnica de apresentação das personagens por elas mesmas. No texto, o cantor apresenta a família do governador Abaschvíli; no palco, há uma mescla entre a fala do cantor e a presença das personagens que vão se apresentando ao público. Também é épica a técnica por meio da qual a narração e a encenação se desdobram e justapõem. Uma cena em que Grusche e uma camponesa representam uma ação enquanto duas outras personagens dizem as falas é exemplar desse procedimento. O que temos são personagens narrando a cena enquanto outras mostram os gestos. A imagem a seguir (Figura 2) é de um momento em que um ator assume a função de narrador e, dirigindo-se diretamente à plateia, comenta as ações praticadas por Grusche, em pé, à esquerda. 


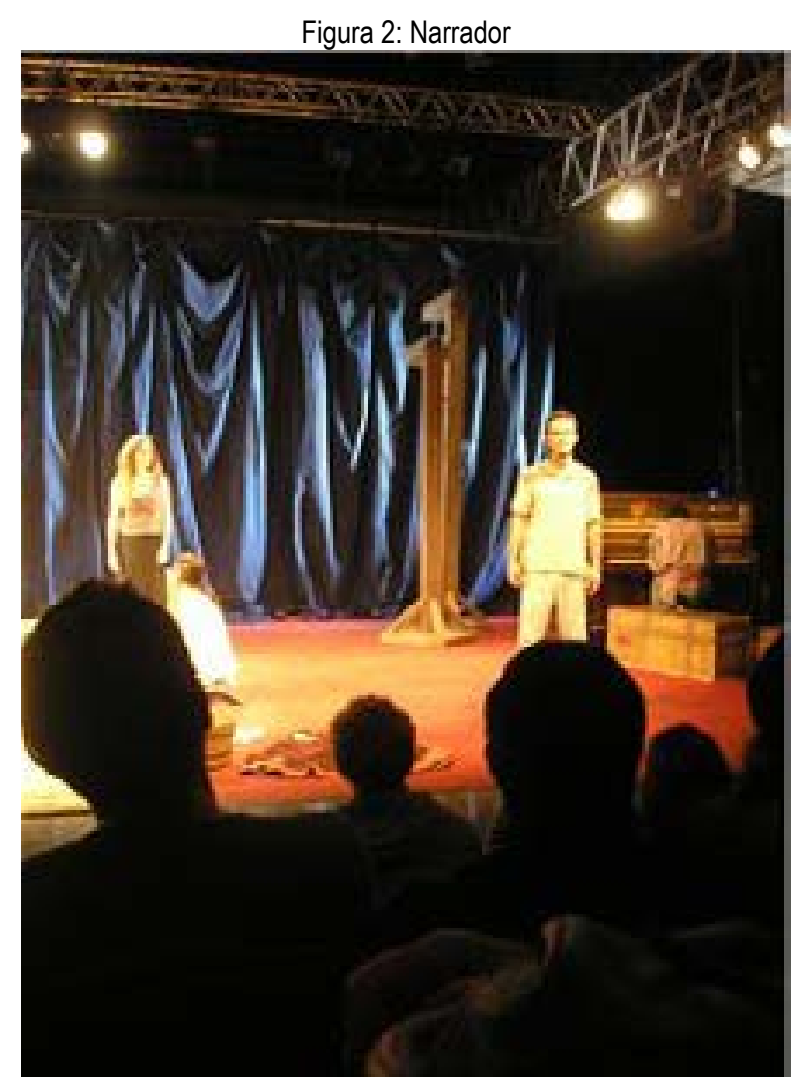

Fonte: Arquivo pessoal. Araraquara, julho 2007

A concepção brechtiana de atuação prevê que o ator se distancie da personagem, numa espécie de desdobramento no qual o ator se torna espectador da sua própria representação. Para alcançar esse objetivo, é preciso, primeiramente, revogar o princípio da identificação entre personagem e ator. $O$ ator brechtiano não "incorpora" uma personagem, anulando-se diante dela; pelo contrário, ele age e observa sua própria ação, simultaneamente. Uma mesma personagem pode ser representada por mais de um ator, o que deixa evidente ao espectador que se trata de jogo cênico, atuação, sem apelo para os sentimentos e emoções das personagens que despertariam empatia no público.

Nesse espetáculo da Companhia do Latão, os bastidores do teatro são colocados em cena, nas laterais do palco, onde estão os objetos de cena já utilizados ou a serem levados ao palco e os instrumentos musicais com os quais executam as músicas previstas para o espetáculo. Também é nas laterais que os atores trocam de roupa, assumindo novas personagens diante dos olhos do espectador. $O$ uso do espaço cênico, portanto, contribui claramente para o efeito de distanciamento, para manter o receptor desperto para a natureza de simulação/jogo inerente ao teatro. Nas figuras 3 e 4 é possível observar a utilização do espaço e distribuição do aparato cênico nas laterais do palco; como a fotografia é do momento do intervalo, os atores estão fora de cena. Já na figura 5 temos um ator sentado na lateral "assistindo" ao espetáculo, com outros três atores em pé atrás dele que acompanham a ação à espera do momento de voltar à cena. Não há simulação alguma: o ator é sempre ator, sem confundir-se com a personagem que representa. 


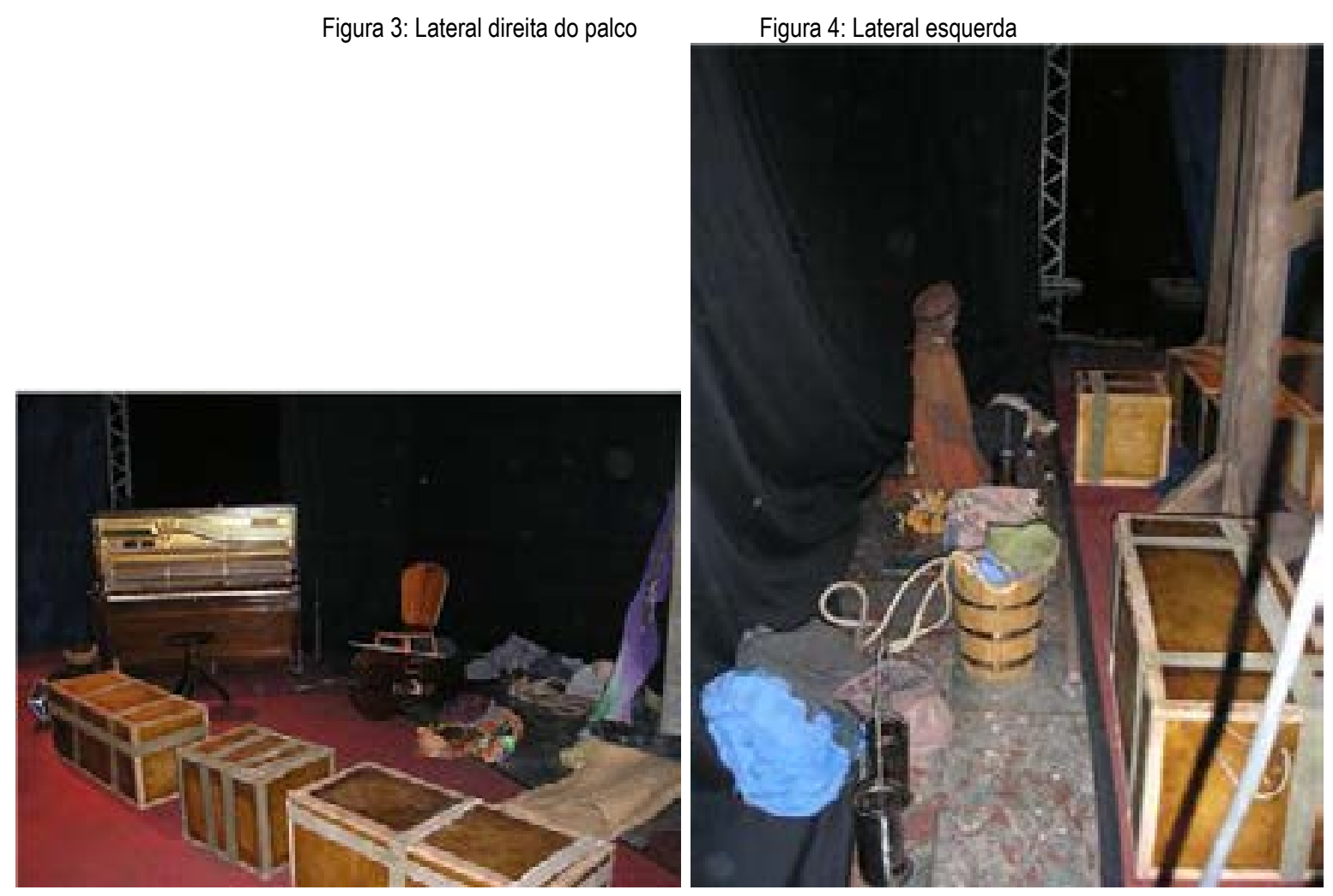

Fonte: Acervo pessoal. Araraquara, julho 2007

Figura 5: Ator-espectador

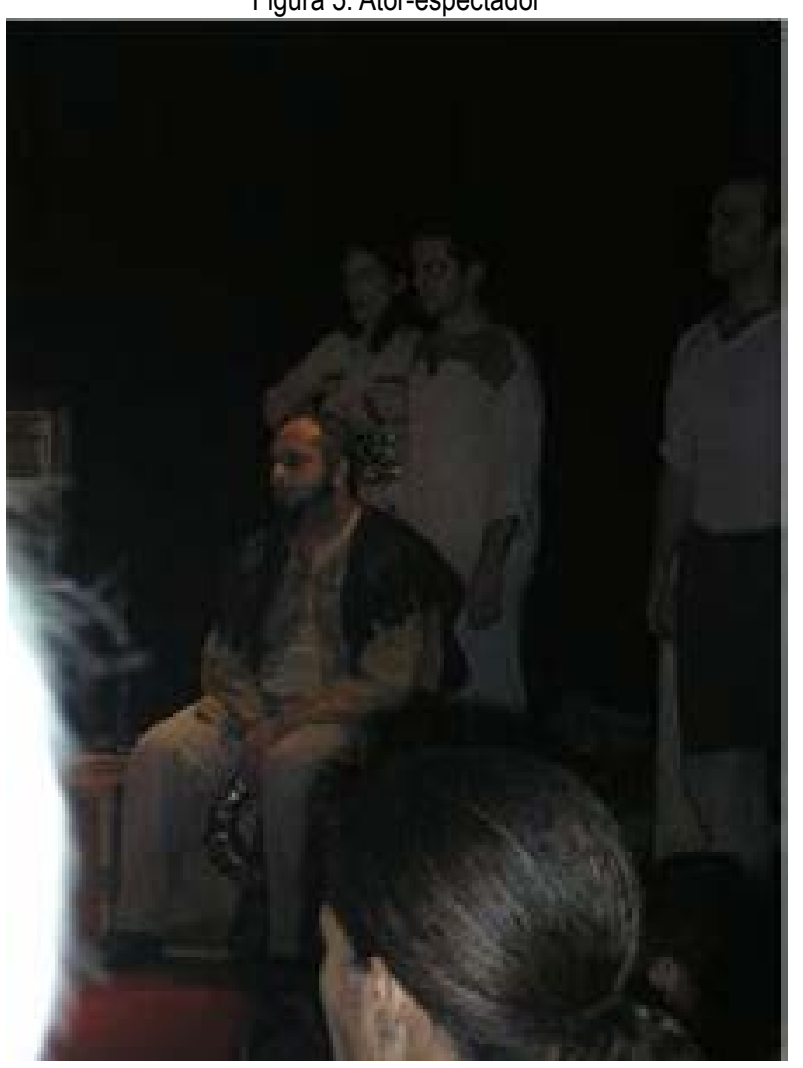

Fonte: Acervo pessoal. Araraquara, julho 2007

Os recursos épicos, na teoria de Brecht, têm uma função muito particular. Além de renovar a forma dramática, como aponta Szondi (2003), estabelecendo novos rumos para o teatro moderno, Brecht concebe o teatro como instrumento de reflexão, de conscientização política. Para isso, o dramaturgo desenvolve o conceito de efeito 
de distanciamento. No texto "Efeitos de distanciamento na arte dramática chinesa", Brecht considera a empatia - isto é, a identificação dos sentimentos do espectador com os sentimentos das personagens, estes por sua vez confundidos com os sentimentos do ator - um fundamento da arte dramática aristotélica. O efeito de distanciamento é exatamente o contrário e Brecht exemplifica comentando tentativas de dramaturgia não-aristotélica nas quais se desenvolvesse

a representação de tal modo que fosse impossível ao espectador meter-se na pele das personagens da peça. A aceitação ou a recusa das palavras ou das ações das personagens devia efetuar-se no domínio do consciente do espectador, e não, como até a esse momento, no domínio do seu subconsciente. (Brecht, ([19- ], p.89)

Portanto, o uso de recurso épicos - no texto ou na cena - tem por objetivo último levar o espectador à reflexão, ao pensamento crítico. O teatro é uma forma de lazer e prazer, mas é também um instrumento de conscientização política a partir da qual a transformação social se torna possível.

Para tanto, é preciso que o espectador seja lembrado todo o tempo de estar diante de uma representação, de que aquilo é teatro, encenação, objetivo alcançado com eficácia pela alocação dos bastidores nas laterais do palco, possibilitando que a) os espectadores observem a troca de figurinos e de objetos de cena; b) os atores sejam também espectadores da encenação, pois ficam ao lado da cena aguardando seu momento de atuação; c) os espectadores percebam a representação como algo pensado e mostrado ao público não como mundo autônomo, mas como criação artística humana.

A música, executada ao vivo, também provoca efeito de distanciamento e interrupção do fluxo da ação. Ao contrário de formas do teatro dramático, como o melodrama, por exemplo, a música em Brecht não serve para embalar a ação e comover o espectador; ao contrário, muitas vezes a música opera como efeito de dissonância (ação triste combinada com música efusiva). Por isso, tal como no texto, o cantor também é uma presença constante no espetáculo, cuja figura parece alinhavar as cenas da peça. Ao final da cena em que o soldado Simon Chachava retorna da guerra e reencontra Grusche à margem do rio, temos a intervenção do cantor/narrador; ele manifesta os pensamentos da criada, assumindo uma posição semelhante à de um narrador onisciente capaz de saber tudo sobre a personagem:

\footnotetext{
O que ela pensa e não fala, vamos tentar escutar:

Soldado, enquanto estavas na batalha, tua batalha de sangue e de fel, achei uma criança abandonada, e aí meu coração não resistiu.

Fiquei com pena e tomei conta dela, catei migalhas pelo chão me desgracei pelo que nem meu era: um estranho [...]. (Brecht, 1992, p. 252).
}

Na encenação, além de enunciar o que Grusche pensa e sente, o narrador verbaliza os gestos das personagens, criando uma simultaneidade entre narração e representação: enquanto o cantor narra os gestos, as personagens os representam. A próxima 
imagem ilustra o corte no fluxo da ação por meio da execução de uma canção.

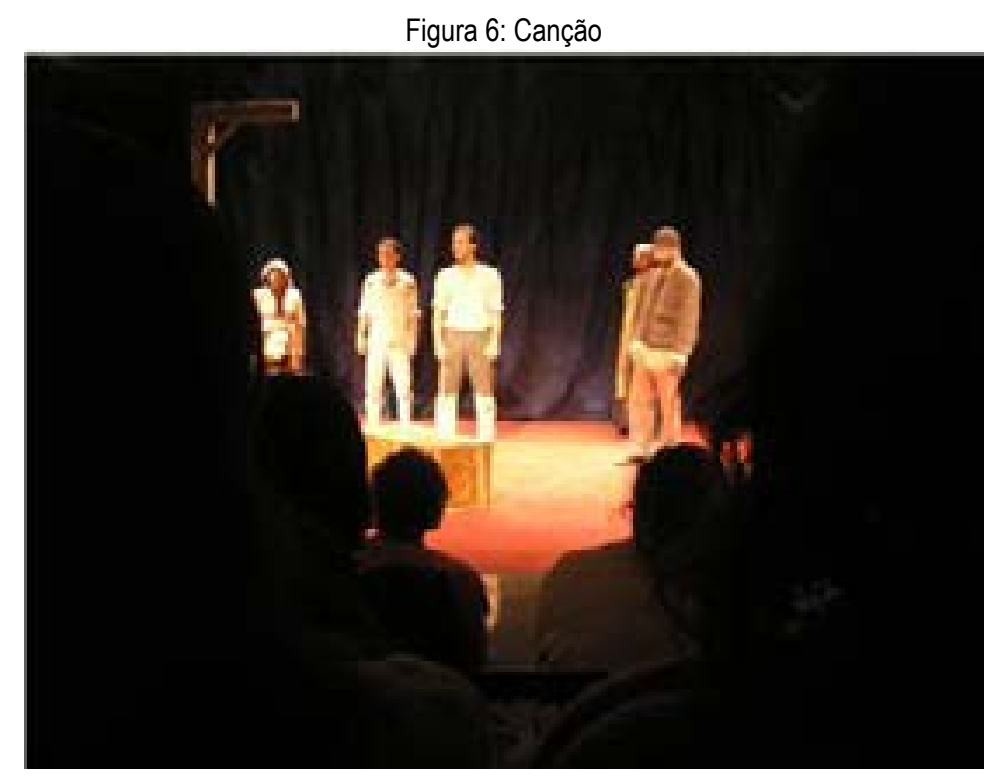

Fonte: Acervo pessoal. Araraquara, julho 2007

Brecht e a Companhia do Latão encontram no teatro épico um caminho para a exposição dialética das contradições históricas que cercam o direito à propriedade. Conforme Szondi (2003), as modificações formais que levam à configuração do drama moderno são uma demanda dos novos tempos e temas, logo, para que o teatro seja e continue sendo "[...] uma arma de libertação [...] é necessário criar as formas teatrais correspondentes. É necessário transformar." (Boal, 1977, p.1). Ao re(a)presentar a fábula de $O$ círculo de giz caucasiano para o público do século $\mathrm{XXI}^{6}$, o Latão reatualiza Brecht, trazendo as questões do final da Segunda Guerra para um contexto brasileiro, contemporâneo, inevitavelmente político.

\section{Considerações finais}

Segundo Paolo Chiarini (1967, p. 138), o que Brecht chama de "dramaturgia não aristotélica" equivale a uma "poética brechtiana do drama", isto é, o conjunto de suas ideias estéticas acerca da função da arte, do objetivo do teatro, da necessidade de nova(s) forma(s) dramática(s) em sintonia com os tempos modernos. A fim de concretizar essa poética do drama, o encenador alemão elabora as técnicas do teatro épico, que para Chiarini configuram a "poética brechtiana do espetáculo". Somando uma poética à outra fica claro que ambas colaboram para a afirmação da dimensão política da arte teatral, dimensão cultivada tanto por Brecht quanto pela companhia teatral paulistana.

O círculo de giz caucasiano é uma fábula sobre a ambição dos que exercem o poder e de como a humanidade se perde quando o dinheiro fala mais alto, condição materializada na frieza da mãe biológica que despreza o bem-estar da criança na ânsia de reconquistar, por meio dela, a posição aristocrática perdida. Valmir Santos, em reportagem da Folha de São Paulo, destaca a vocação do grupo teatral a partir do

${ }^{6}$ Houve remontagem do espetáculo em 2014. 
tema da peça montada para marcar o cinquentenário da morte de Brecht no Brasil:

"O Círculo" abre e fecha falando de terra. Questiona em que medida sua ocupação é justa ou legal, prato cheio para uma companhia que busca pensar Brecht no contexto do capitalismo atual e do Brasil, sociedade da periferia do mundo, no dizer de Carvalho. (Santos, 2006, p. E4).

A mesma reportagem se abre com uma afirmação contundente - talvez desatualizada em relação às manifestações populares recentes (refiro-me a 2013): "A militância política pode estar em baixa, mas dá sinais de sobrevida no teatro". De fato, o teatro não tem abandonado a militância política e não se trata de sobrevida, mas de condição da experiência teatral, afinal, as palavras de Augusto Boal (1977, p. 1) ecoam mesmo em práticas contemporâneas experimentais, aparentemente distantes do político: "[...] Todo teatro é necessariamente político, porque políticas são todas as atividades do homem, e o teatro é uma delas. Os que pretendem separar o teatro da política, pretendem conduzir-nos ao erro - e esta é uma atitude política".

Para Fernando Kinas (2013), o teatro de grupo no Brasil contemporâneo tem de operar sobre uma tríade incontornável - teatro, poder, verdade. É esse o enfrentamento aceito pela Companhia do Latão. Se para Brecht o fundamental é demonstrar como o recrudescimento do capitalismo desumaniza o humano, o Latão assume-se herdeiro da vocação política do teatro "[...] de formar pessoas aptas à (sic) decifrar sua própria situação histórica" (Kinas, 2013, p. 31) para o que contribui incisivamente a inserção do vídeo sobre o MST como abertura do espetáculo, permitindo ao grupo atualizar questões históricas.

A história de Grusche fala sobre o poder, a atuação de Asdak nos coloca em face da verdade e os recursos épicos de que lança mão o espetáculo possibilitam um reencontro com a dimensão política do teatro brechtiano, afinal, "[...] nenhuma representação é neutra, [pois] que a forma escolhida já contém juízos e que a escolha formal é política" (Costa, 2013, p. 17).

\section{Referências}

BLOG da Companhia do Latão. Disponível em <http://www.companhiadolatao. com.br/blog/?page_id=320>. Acesso em 10 fev. 2016.

BOAL, Augusto. Teatro do oprimido e outras poéticas políticas. Rio de Janeiro: Civilização Brasileira,1977.

BRECHT, Bertolt. Estudos sobre teatro. Coligidos por Siegfried Unseld. Portugal: Portugália Editora, [19- ].

O círculo de giz caucasiano. In: Teatro completo. Rio de Janei

ro: Paz e Terra, 1992. v. 9, p.179-296. 
CARVALHO, Sérgio de; MARCIANO, Márcio. Companhia do Latão 7 peças. São Paulo: Cosac Naify, 2008.

CHIARINI, Paolo. Bertolt Brecht. Tradução Fátima de Souza. Rio de Janeiro: Ci vilização Brasileira, 1967.

COSTA, Iná Camargo. Prefácio. In: CARVALHO, Sérgio de; MARCIANO, Márcio. Companhia do Latão 7 peças. São Paulo: Cosac Naify, 2008. p. 15-29.

KINAS, Fernando. Teatro, verdade e poder. aParte XXI - Revista do Teatro da Universidade de São Paulo. no. 6, 1ํ. sem. 2013, p. 29-38.

MAGALDI, Sábato. Prefácio. In: ROSENFELD, Anatol. O teatro épico. São Paulo: Perspectiva, 1997. p. 7-10.

MARCIANO, Márcio. Brecht em cheio. O Círculo de giz caucasiano pela Compa nhia do Latão. Revista Sala Preta, v. 6, 2006, p. 175-178.

PEIXOTO, Fernando. Brecht: uma introdução ao teatro dialético. Rio de Janeiro: Paz e Terra, 1981. (Coleção Teatro, 6).

ROSENFELD, Anatol. O teatro épico. 3. ed. 1. reimp. São Paulo: Perspectiva, 1997.

SANTOS, Valmir. Cia do Latão atualiza fábula de Brecht. Folha de São Paulo, Ca derno llustrada, 09 ago. 2006, p. E4.

STAIGER, Emil. Conceitos fundamentais da poética. Tradução Celes Aída Galeão. 3. ed. Rio de Janeiro: Tempo Brasileiro, 1997.

SZONDI, Peter. Teoria do drama moderno (1880-1950). Tradução Luiz Sérgio Rêpa. São Paulo: Cosac Naify, 2003.

WILLETT, John. O teatro de Bertolt Brecht: visto de oito aspectos. Tradução Ál varo Cabral. Rio de Janeiro: Zahar, 1967.

Recebido em: 30/04/2016 Aprovado em: 01/07/2016 